\title{
The Overview of Nutritional Status of Children Between 6-24 Months with Feeding Difficulties in Working Area of North Cimahi Primary Health Center
}

\author{
Elly Noer Rochmah ${ }^{1,2, *}$, Dini Ismayanti Permana ${ }^{2}$, Sutedja $^{3}$, Nadhilah Lailani ${ }^{4}$ \\ ${ }^{1}$ Department of Pediatrics, ${ }^{2}$ Faculty of Medicine, ${ }^{3}$ Department of Public Health, ${ }^{4}$ Faculty of Medicine \\ ${ }^{1}$ RS TK II Dustira, ${ }^{2,3}$ Jendral Achmad Yani University, ${ }^{4}$ Andalas University \\ ${ }^{1,2,3}$ Cimahi, ${ }^{4}$ Padang, Indonesia \\ *elly.noer@fk.unjani.ac.id
}

\begin{abstract}
Feeding difficulties in children is the lack of appetite or inability to eat and refuse certain foods. Feeding difficulties can be caused by several factors, specifically organic and non-organic factors. Feeding difficulties will be at high-risk of causing nutritional problems if not treated as they get older. The objective of this study is to determine the nutritional status of children aged 6 to 24 months who have feeding difficulties in the working area of the North Cimahi Primary Health Care Centre. This study was cross sectional and conducted in January 2018. The sample consisted of 48 children who had feeding difficulties. This study used questionnaires data and also measures children's height and weight. The data was analysed descriptively. The results showed that the average age of children who have feeding difficulties in the working area of the North Cimahi Primary Health Care Centre was 15,40 months. The majority of children who have feeding difficulties were males $(54,2 \%)$. The types of nutritional status in children who have feeding difficulties ranged from normal $(\mathbf{7 0 , 8 \%})$ to malnutrition $(27,1 \%)$ and severe malnutrition $(2,1 \%)$. The types of feeding difficulties were inappropriate feeding practice $(81,3 \%)$, parental misperception $(16,7 \%)$, and sensory food aversions $(2,1 \%)$. The types of nutritional status in children with inappropriate feeding practice ranged from normal $(64,1 \%)$ to malnutrition $(33,3 \%)$ and severe malnutrition $(2,6 \%)$, while in parental misperception the nutritional status was all normal $(100,0 \%)$ and sensory food aversions misperception the nutritional status was all normal $(\mathbf{1 0 0 , 0 \% )}$.
\end{abstract}

Keywords—children aged 6-24 months, feeding difficulties, nutritional status

\section{INTRODUCTION}

Children aged 6-24 months are in golden period of growth and development. Golden period is critical period and mostly determined by the nutrition they get. The source of nutrition for infant aged 0-6 months is breast milk or formula milk. When the infant is 6 months old, they should start getting their first food or also called complementary food because breast milk is no longer able to provide energy, protein, iron, vitamins D and A. The absence of a good recognition of infants in complementary foods would lead to feeding difficulties in children under three years of age [1-3].

Feeding difficulties is a condition when the child has less appetite or unable to eat and refuses certain foods. Feeding difficulties can be caused by several factors, specifically organic and non-organic factors. Organic factors can be caused by congenital disease, abnormality of the intestinal tract, while nonorganic factors caused by influence of parents, socioeconomic habit of the family, and way of diet and habit [2].

There are some classifications of feeding difficulties, as inappropriate feeding practice, parental misperception, sensory food aversions, infantile anorexia, and post traumatic feeding disorder. Inappropriate feeding practice occurs because there are inappropriate and prolong feeding time, feeding while playing, forcing children to eat certain portion of meals, etc. Parental misperception caused by the misconception of parents because children eat too little, and parents force them to eat until they are traumatized. While sensory food aversions happen when children get picky on their food [4-6].

Based on Pediatric Nutrition Care and Metabolic Disease of IDAI, inappropriate feeding practice is one of the leading causes of feeding difficulties in children [5]. The study conducted by Elva, found that $38(92,7 \%)$ children had feeding difficulties with inappropriate feeding practice type [7]. The other study done by Loraine Harinda in 2012, found that feeding difficulties was caused mostly by inappropriate feeding practice $(96,8 \%)$ and followed by parental misperception $(3,2 \%)[8]$.

Parents, doctors, and other health care professionals often face nutritional challenges in children. Feeding difficulties in children, especially at 6 to 24 months of age, can lead to nutritional disorder and then turn into malnutrition. 
Malnutrition can alter children's interaction with their environment, and if this situation continues, it will lead to poor child's growth and development. According to a previous study of preschool children in Jakarta in 2011, feeding difficulties were experienced by children with mild to moderate malnutrition with percentage $33,6 \%$ and $44,5 \%$ [9-12].

According to data of Indonesia's Health Profile in 2015, there were 26.518 cases of malnutrition in Indonesia, including 2.895 cases in West Java and 448 in Cimahi. Based on data from Cimahi Health Office in 2016, there are 42 malnutrition children and 251 underweight children at the North Cimahi Primary Health Care Centre $[1,13,14]$.

However, study about an overview of nutritional status of children between 6-24 months who have feeding difficulties, specifically in Cimahi City has never been conducted. According to the data above, the researcher was interested in analysing the overview of nutritional status of children between 6-24 months who have feeding difficulties in working area of North Cimahi Primary Health Care Centre.

\section{MATERIALS AND METHODS}

This study was cross sectional and conducted in January 2018. This study used questionnaires about feeding difficulties and also measures children's height and weight. The subject of the study was children aged 6 to 24 months who had feeding difficulties and lived in working area of North Cimahi Primary Health Care Centre and should not have other disorders, such as cleft lip, chronic diarrhea, or food allergy. The sample consisted of 48 children who had feeding difficulties and used multistage random sampling as the sampling technique. The data was analysed descriptively.

\section{RESULTS AND DISCUSSION}

A. Subjects' Characteristics Based on Age of Children Aged 6 to 24 Months with Feeding Difficulties in Working Area of North Cimahi Health Care Center

TABLE I. SubJeCts’ Characteristic BASED ON AGE

\begin{tabular}{|l|l|}
\hline \multicolumn{2}{|c|}{ Age (Months) } \\
\hline Mean (SD) & $15,40(5,59)$ \\
\hline Median & 16 \\
\hline
\end{tabular}

Table 1 shows that the average age of children with feeding difficulties in the study area was 15,40 months, with standard deviation of 5,59 months, and median of 16 months. The previous study done by Darwati, et al in 2012, found that the mean age of children with feeding difficulties was 14,08 months [15].

When children reach 16 months old, they become active and playful, so that they will be easily irritable and difficult to eat. They also have a great curiosity, have their own taste in food, which makes them picky on food. Sometimes children are busy exploring the world around them, so they can easily get distracted and forget to eat $[5,16]$

\section{B. Subjects' Characteristics Based on Gender of Children Aged 6 to 24 Months with Feeding Difficulties in Working Area of North Cimahi Health Care Center}

TABLE II. SUBJECTS' CHARACTERISTIC BASED ON GENDER

\begin{tabular}{|l|c|c|}
\hline Gender & n & \% \\
\hline Boys & 26 & 54,2 \\
\hline Girls & 22 & 45,8 \\
\hline Total & 48 & 100,0 \\
\hline
\end{tabular}

According to Table 2, it shows that children with feeding difficulty in the study area were predominantly boys, with 26 boys out of 48 samples in total $(54,2 \%)$. The results were consistent with previous study conducted by Darwati, et al in 2017, which found that $70(58,8 \%)$ boys and $49(41,2 \%)$ girls had feeding difficulties. However, these results were different from other studies done by Loraine Harinda in 2012 in Semarang, which found that the feeding difficulties were mostly found in girls, with a percentage of $53,8 \%$ or 50 girls out of 93 samples in total $[8,15]$

The results of this study occurred because there were differences in the population of children by gender. The number of boys in the study area was 1647 whereas girls were 1520. The other causes were explained by other studies conducted by Powell, et al in 2011, found that feeding difficulties were mostly found in boys because they easily had angry attacks or tantrum compared to girls [17]

\section{The Overview of Nutritional Status of Children Aged 6 to 24 Months with Feeding Difficulties in Working Area of North Cimahi Health Care Center}

TABLE III. THE OVERVIEW OF NUTRITIONAL STATUS

\begin{tabular}{|l|l|l|}
\hline Nutritional Status & \multicolumn{1}{|c|}{$\mathbf{~}$} & \multicolumn{1}{|c|}{} \\
\hline Obesity & 0 & 0 \\
\hline Overweight & 0 & 0 \\
\hline Normoweight & 34 & 70,8 \\
\hline Underweight & 13 & 27,1 \\
\hline Malnutrition & 1 & 2,1 \\
\hline Total & 48 & 100,0 \\
\hline
\end{tabular}

Table 3 shows that the majority of children with feeding difficulties in the study areas had a normoweight of $34(70,8 \%)$ children, followed by $13(27,1 \%)$ underweight children and 1 $(2,1 \%)$ malnutrition child. The previous study conducted by Loraine Harinda in 2012 in Semarang, found that almost all preschool children with feeding difficulties were in a normoweight state with percentage of $90,3 \%$, followed by underweight $(5,4 \%)$, overweight $(1,1 \%)$, and obesity $(3,2 \%)$ Feeding difficulties have negative effect on the feeding process and also the nutritional status of the children. For example, when children get distracted by something such as playing or 
watching TV while eating, they will take more time to eat $[8,18,19]$.

D. The Overview of Feeding Difficulties' Classification of Children Aged 6 to 24 Months with Feeding Difficulties in Working Area of North Cimahi Health Care Center

TABLE IV. THE OVERVIEW OF FEEDING DIFFICULTIES's CLASSIFICATION

\begin{tabular}{|l|l|l|}
\hline Classification of Feeding Difficulties & n & \multicolumn{1}{|c|}{$\%$} \\
\hline Parental misperception & 8 & 16,7 \\
\hline Inappropriate feeding practice & 39 & 81,3 \\
\hline Anoreksia infantil & 0 & 0 \\
\hline Sensory food aversions & 1 & 2,1 \\
\hline Post traumatic feeding disorder & 0 & 0 \\
\hline Total & 48 & 100,0 \\
\hline
\end{tabular}

According to Table 4, it shows that the common type of feeding difficulties in study areas was inappropriate feeding practice of 39 children $(81,3 \%)$, then followed by 8 children $(16,7 \%)$ with parental misperception type and 1 child $(2,1 \%)$ sensory food aversions type. The results were consistent with previous study conducted by Loraine Harinda (2012) found that feeding difficulties was caused mostly by inappropriate feeding practice $(96,8 \%)$ and followed by parental misperception $(3,2 \%)$ [8].
Inappropriate feeding practice occurs because there are inappropriate and prolong feeding time, feeding while playing, forcing children to eat certain portion of meals, etc. The lack of information about proper nutrition causes a lot of parents not feeding their child properly. The study done by Powell, et al, found that $25 \%$ to $50 \%$ of parents did not feed their child properly, resulting in child refusing to eat. The other study conducted in England, stated that parents still had bad habits when feeding their children, such as playing $(74,7 \%)$ or watching television while eating $(66,7 \%)[17,18,20]$.

Parental misperception caused by the misconception of parents because children eat too little, and parents force them to eat until they are traumatized. In this type of feeding difficulties, the child shows a normal appetite and growth. While sensory food aversions happen when children get picky on their food. The child will show an expression of dislike by covering his mouth, taking food out of his mouth, or vomiting it, and refusing to continue eating. The rejection of food is caused by the fact that the child does not like the taste, texture, temperature, and smell of certain foods [5,21].

\section{E. The Overview of Nutritional Status Based on Feeding} Difficulties' Classification of Children Aged 6 to 24 Months with Feeding Difficulties in Working Area of North Cimahi Health Care Center

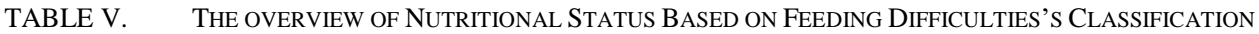

\begin{tabular}{|c|c|c|c|c|c|c|c|c|}
\hline \multirow{3}{*}{ Feeding Difficulties } & \multicolumn{8}{|c|}{ Nutritional Status } \\
\hline & \multicolumn{2}{|c|}{ Normo-weight } & \multicolumn{2}{|c|}{ Under-weight } & \multicolumn{2}{|c|}{ Malnutrition } & \multicolumn{2}{|c|}{ Total } \\
\hline & $n$ & $\%$ & $n$ & $\%$ & $n$ & $\%$ & $n$ & $\%$ \\
\hline Parental misperception & 8 & 100,0 & 0 & 0,0 & 0 & 0,0 & 8 & 100,0 \\
\hline Inappropriate feeding practice & 25 & 64,1 & 13 & 33,3 & 1 & 2,6 & 39 & 100,0 \\
\hline Anoreksia infantil & 0 & 0 & 0 & 0 & 0 & 0 & 0 & 0 \\
\hline Sensory food aversions & 1 & 100,0 & 0 & 0,0 & 0 & 0,0 & 1 & 100,0 \\
\hline Post traumatic feeding disorder & 0 & 0 & 0 & 0 & 0 & 0 & 0 & 0 \\
\hline Total & 34 & 70,8 & 13 & 27,1 & 1 & 2,1 & 48 & 100,0 \\
\hline
\end{tabular}

According to Table 5, it shows that feeding difficulties with the type of parental misperception was all normoweights of 8 children $(100 \%)$. These results were consistent with the study conducted by Loraine Harinda in 2012 in Semarang, which found 3 children $(3,2 \%)$ of normoweight had feeding difficulties with the type of parental misperception. The other study done by Darwati, et al in 2012 in Jayapura Health Care Centre, found that there were 20 normoweight children $(16,8 \%)$ with feeding difficulties mostly caused by parental misperception type. The same results were found in other study by Patricia, that $4,2 \%$ children had feeding difficulties with the type of parental misperception $[8,15,22,23]$.

In children who have feeding difficulty with the type of parental misperception, all nutritional status of the child shows a normoweight. Parents have indeed applied the basic principle of proper nutrition, but sometimes they have misjudged the portion of their children's food. They do not understand that the quantity of food consumed by each child varies $[5,20]$.
Besides, in feeding difficulties with the type of inappropriate feeding practice were predominantly with normoweight of 25 children $(64,1 \%)$, followed by 13 underweight children $(33,3 \%)$ and 1 malnutrition children $(2,6 \%)$. These finding was consistent with previous study conducted by Loraine Harinda in 2012, found that there were 90 normoweight children $(96,8 \%)$ had feeding difficulties with the type of inappropriate feeding practice. This indicates that parents' knowledge of the basic rules of feeding practice is still weak $[8,24]$.

The study also found that there was only 1 normoweight child $(100 \%)$ with feeding difficulties with the type of sensory food aversions. The previous study done by Sari, found that there were $46,7 \%$ normoweight children, $30 \%$ underweight children, and $23,2 \%$ overweight children with feeding difficulties in sensory food aversions type [25]. 


\section{CONCLUSIONS}

According to the study, the following conclusions were obtaining: the average age of children with feeding difficulties was 15,40 months and were predominantly boys $(54,2 \%)$. The overview of nutritional status of children with feeding difficulties in the study areas was normoweight $(70,8 \%)$. The overview of classification of feeding difficulties was inappropriate feeding practice $(81,3 \%)$.

Based on this study, the author emphasizes the importance of providing education to executives of integrated health centres and parents regarding feeding difficulties in children, the consequences that may occur, and its management. Besides, author also suggests for parents to consult their child with paediatricians if their child often refuses to eat or just wants to eat certain foods even though the child looks healthy. Last, for healthcare centre to optimize the Supplementar Recovery Feeding (PMT-P) program to improve children's nutritional status and to satisfy the nutritional needs of children in order to achieve a good nutritional state and nutritional conditions depending on the age of the child.

\section{REFERENCES}

[1] Ikatan Dokter Anak Indonesia, Rekomendasi Ikatan Dokter Anak Indonesia. Jakarta, 2015.

[2] D.I. Thurnham, "Adequate Nutrient Intakes For Infancy," Sight and Life, vol. 27, no. (2), pp. 32-35, 2013.

[3] B.R. Carruth, P.J. Ziegler, A. Gordon and S.I. Barr, "Prevalence of picky eaters among infants and toddlers and their caregivers' decisions abou offering a new food," J Am Diet Assoc., vol. 104, no. (1), pp. 57-64, 2004.

[4] C.M. Wright, K.N. Parkinson, D. Shipton and R.F. Drewett, "How do toddler eating problems relate to their eating behavior, food preferences, and growth," American Academy of Pediatrics, vol. 120, pp. 1069-1075, 2007.

[5] D.R. Sjarif, Masalah makan pada batita. Penelitian pendahuluan. UKK Nutrisi dan Penyakit Metabolik. Ikatan Dokter Anak Indonesia, 2011

[6] A.C. Bernard-Bonnin, "Feeding problems of infants and toddlers," Canadian Family Physician, vol. 52, no. (10), pp. 1247-1251, 2006

[7] E. Kadarhadi, Pengaruh konseling dengan "feeding rules" terhadap status gizi anak dengan kesulitan makan. Semarang: Universitas Dipenogoro Semarang, 2012.

[8] L. Harinda, Proporsi dan status gizi pada anak prasekolah dengan kesulitan makan di Semarang (studi kasus di Kelurahan Tandang dan Sendangguwo). Semarang: Universitas Dipenogoro Semarang, 2012.
[9] S. Soedibyo and R.L. Mulyani, "Kesulitan makan pada pasien: survei di unit pediatri rawat jalan," Sari pediatri, vol. 11, no. (2), pp. 79-84, 2016.

[10] A.K. Yousafzai, S. Filteau and S. Wirz, "Feeding difficulties in disabled children leads to malnutrition: experience in an Indian slum," British Journal of Nutrition, vol. 90, no. (6), pp. 1097-1106, 2003.

[11] H.B. Henningham and S.G. McGregor, Gizi dan perkembangan anak Dalam : Gibney MJ, Margetts BM, Kearney MK, Arab Lenore. Gizi Kesehatan Masyarakat. Jakarta: Penerbit Buku Kedokteran EGC, 2015.

[12] A.M. Beck, M. Holst and H.H. Rasmussen, "Efficacy of the Mini Nutritional Assessment to predict the risk of developing malnutrition or adverse health outcomes for old people. e-SPEN," the European eJournal of Clinical Nutrition and Metabolism, vol. 3, no. (3), pp. e102e107, 2008

[13] P. Vanessa, Proporsi dan status gizi anak usia 6-24 bulan dengan kesulitan makan di Semarang. Semarang: Universitas Dipenogoro Semarang, 2012.

[14] Kementrian Kesehatan Provinsi Jawa Barat, Profil Kesehatan Provinsi Jawa Barat. Bandung, 2015.

[15] D. Darwati, M. Mexitalia, S. Hadiyanto, F. Hartanto and S.A Nugraheni, "Pengaruh Intervensi Konseling Feeding Rules dan Stimulasi Terhadap Status Gizi dan Perkembangan Anak di Posyandu Kabupaten Jayapura," Sari Pediatri, vol. 15, no. (6), pp. 377-384, 2016.

[16] I. Chatoor, Diagnosis and treatment of feeding disorder, in infant, toddlers, and young children. Washington DC: Zero To Three, 2009.

[17] F.C. Powell, C.V. Farrow and C. Meyer, "Food avoidance in children The influence of maternal feeding practices and behaviours," Appetite, vol. 57, no. (3), pp. 683-692, 2011

[18] M. Mexitalia, Kesulitan makan pada anak: diagnosis dan tatalaksana. Simposium mengelola pasien anak dalam praktek sehari-hari. Semarang, 2011.

[19] Ikatan Dokter Anak Indonesia, Kurva Pertumbuhan WHO [Online] Retrieved from: http://www.idai.or.id/professional-resources/growthchart/kurva-pertumbuhan-who. [Accessed on July 3rd, 2017].

[20] C.M. Wright, K.N. Parkinson, D. Shipton and R.F. Drewett, "How do toddler eating problems relate to their eating behavior, food preferences, and growth?" Pediatrics, vol. 120, no. (4), pp. e1069-e1075, 2007.

[21] A.C. Bernard-Bonnin, "Feeding problems of infants and toddlers," Canadian Family Physician, vol. 52, no. (10), pp. 1247-1251, 2006.

[22] P. Vanessa, Proporsi dan status gizi anak usia 6-24 bulan dengan kesulitan makan di Semarang. Semarang: Universitas Dipenogoro Semarang, 2012.

[23] S. Sudjatmoko," Masalah kesulitan makan pada anak," Damianus Journal of Medicine, vol. 10, pp. 35-36, 2011.

[24] A.C. Bernard-Bonnin, "Feeding problems of infants and toddlers," Canadian Family Physician, vol. 52, no. (10), pp. 1247-1251, 2006.

[25] S. Rahayu, Gambaran perilaku picky eater, pola makan dan status giz anak autis di SLB Negeri Semarang. Semarang: Universitas Muhammaddiyah Surakarta, 2016. 